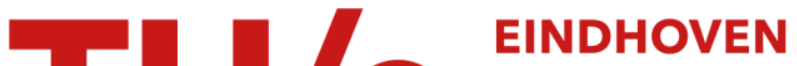 UNIVERSITY OF TECHNOLOGY
}

\section{Application of thermally activated municipal solid waste incineration (MSWI) bottom ash fines as binder substitute}

Citation for published version (APA):

Tang, P., Florea, M. V. A., Spiesz, P. R., \& Brouwers, H. J. H. (2016). Application of thermally activated municipal solid waste incineration (MSWI) bottom ash fines as binder substitute. Cement \& Concrete Composites, 70, 194-205. https://doi.org/10.1016/j.cemconcomp.2016.03.015

\section{Document license:}

TAVERNE

DOI:

10.1016/j.cemconcomp.2016.03.015

Document status and date:

Published: 01/07/2016

\section{Document Version:}

Publisher's PDF, also known as Version of Record (includes final page, issue and volume numbers)

\section{Please check the document version of this publication:}

- A submitted manuscript is the version of the article upon submission and before peer-review. There can be important differences between the submitted version and the official published version of record. People interested in the research are advised to contact the author for the final version of the publication, or visit the $\mathrm{DOI}$ to the publisher's website.

- The final author version and the galley proof are versions of the publication after peer review.

- The final published version features the final layout of the paper including the volume, issue and page numbers.

Link to publication

\section{General rights}

Copyright and moral rights for the publications made accessible in the public portal are retained by the authors and/or other copyright owners and it is a condition of accessing publications that users recognise and abide by the legal requirements associated with these rights.

- Users may download and print one copy of any publication from the public portal for the purpose of private study or research.

- You may not further distribute the material or use it for any profit-making activity or commercial gain

- You may freely distribute the URL identifying the publication in the public portal.

If the publication is distributed under the terms of Article 25fa of the Dutch Copyright Act, indicated by the "Taverne" license above, please follow below link for the End User Agreement:

www.tue.nl/taverne

Take down policy

If you believe that this document breaches copyright please contact us at:

openaccess@tue.nl

providing details and we will investigate your claim. 


\title{
Application of thermally activated municipal solid waste incineration (MSWI) bottom ash fines as binder substitute
}

\author{
P. Tang a, *, M.V.A. Florea ${ }^{\text {a }}$, P. Spiesz ${ }^{\text {a, b }}$, H.J.H. Brouwers ${ }^{\text {a }}$ \\ a Department of the Built Environment, Eindhoven University of Technology, P.O. Box 513, 5600 MB, Eindhoven, The Netherlands
}

${ }^{\mathrm{b}}$ ENCI HeidelbergCement Benelux, The Netherlands

\section{A R T I C L E I N F O}

\section{Article history:}

Received 30 March 2015

Received in revised form

11 February 2016

Accepted 26 March 2016

Available online 30 March 2016

\section{Keywords:}

Incineration bottom ash fines

Characteristic

Treatment

Cement hydration

Mortar strength

Leaching

\begin{abstract}
A B S T R A C T
Untreated municipal solid waste incineration (MSWI) bottom ash fines $(0-2 \mathrm{~mm})$ have poor pozzolanic properties, and contain substances which can pose an environmental risk (e.g. heavy metals and salts). This study investigates combined treatments applied on bottom ash fines (BAF) to increase their reactivity. The treated BAF is compared with both untreated BAF and cement, and its contribution to cement hydration is investigated. Additionally, the utilization of the treated BAF in mortar as cement replacement is tested. Finally, the leaching properties of mortars containing treated and untreated BAF are estimated. According to the results obtained, the 28-day compressive and flexural strengths of mortar with $30 \%$ treated bottom ash are about $16 \%$ and $6 \%$ lower than the reference mortar, respectively. The leaching of contaminants from the crushed mortars with BAF are well under the limit values imposed by Dutch legislation.
\end{abstract}

() 2016 Elsevier Ltd. All rights reserved.

\section{Introduction}

Cement clinker production contributes highly to the worldwide $\mathrm{CO}_{2}$ emission and continuous consumption of raw materials [1,2]. Considering the protection of the environment and sustainable development as a global focus, a reduction of the production and use of cement worldwide is meaningful. In recent years, a significant amount of research has been done on this topic, in which the application of secondary materials as cement replacement attracted extensive attention [3-6]. Furthermore, the successful use of fly ash and ground blast furnace slag in concrete promotes the research focus on other secondary materials, such as incineration wastes [7-10].

Municipal solid waste is incinerated to reduce its mass and volume (by $70 \%$ and $90 \%$, respectively); meanwhile, energy is produced in the form of heat which can be applied for the generation of electricity $[11,12]$. The incineration of solid waste as an effective way to recover energy and decrease the demand of landfill attracts widespread attention [13-17]. However, a considerable amount of solid residues is produced after incineration (typically fly ash, air pollution control ash, bottom ash etc.), of which bottom ash

\footnotetext{
* Corresponding author.

E-mail address: p.tang@tue.nl (P. Tang).
}

accounts for about $80 \%$ by weight [18]. Previous studies on the characteristics of municipal solid waste incineration (MSWI) bottom ash indicated its potential to be applied as building materials substitute in concrete, as cementitious material, sand or aggregates [19-26]. Nevertheless, it is also reported that the application of bottom ash as building material is hindered from the points of view of its environmental and mechanical properties. As an incineration residue, bottom ash contains certain amounts of heavy metals and salts (such as $\mathrm{Sb}, \mathrm{Mo}, \mathrm{Cu}$, chlorides and sulphates) which pose an environmental risk $[26,27]$. Hence, the amounts of these heavy metals and salts need to be reduced before application in the construction field [28,29]. Furthermore, previous research also mentioned the expansion or swelling of concrete caused by the metallic aluminium contained in bottom ash when it is used as aggregate [30,31]. Therefore, a number of commonly used treatments are applied to upgrade the quality of MSWI bottom ash, which can clean the coarse bottom ash sufficiently to make its properties comply with the legislation, such as physical separation, washing treatment, weathering, etc. [32-34]. However, for the fine bottom ash (particle size smaller than $2 \mathrm{~mm}$ ) which contain more leachable contaminants, these methods are not sufficient or cost effective because of their higher surface area and concentration of contaminants.

Several studies focused on the utilization of MSWI waste as 
binder, and it is reported that the bottom ash contributes very little to the cement hydration because of its low pozzolanic properties. According to the research of Li et al. [35], 30\% of cement replacement by bottom ash reduces the compressive strength of mortars by about $26 \%$ after 28 days. However, the leaching properties of the concrete with MSWI bottom ash as binder are well under the limit value of Chinese legislation (GB 5085.3 [36]), which indicates the immobilization of the contaminants in concrete [37]. Therefore, it is considered that, if the reactivity of the MSWI bottom ash can be increased, its application as binder substitute would be enhanced.

According to previous research, thermal treatment on fine MSWI bottom ash is an effective way of increasing its reactivity, as well as reducing its leaching concentration of heavy metals. As reported by Qiao et al. [38], the milled bottom ash is an inert material and thermal treatment at $800{ }^{\circ} \mathrm{C}$ decreased the loss on ignition (LOI) and decomposed calcite, subsequently increasing the reactivity of bottom ash by generating new active phases (mayenite and gehlenite). Furthermore, thermal treatments of bottom ash are also proven to be efficient to reduce the leaching of heavy metals (such as $\mathrm{Cu}$ and $\mathrm{Pb}$ ), by reducing the content of organics which have been linked to higher leaching of these elements [39,40]. Another connection can be made between the $\mathrm{pH}$ of the leachates of thermally treated samples and the variation in leaching of a number of elements, such as Mo, Sb, and $\mathrm{Cu}$ [41-45].

There are multiple studies on the properties, treatment and application of MSWI wastes [8,12,13,19,34]. However, research focused on the treatment and activation of MSWI bottom ash fines $(0-2 \mathrm{~mm})$ is scarce. Hence, the aim of this study is to evaluate the activation of MSWI fine bottom ash $(0-2 \mathrm{~mm})$ by thermal treatment, and its application as cement substitute in mortar. The characteristics of the treated bottom ash samples are determined by means of X-ray diffraction (XRD), X-ray fluorescence (XRF) and scanning electron microscope (SEM). Additionally, isothermal calorimetry is applied to investigate the hydration of the cement with treated bottom ash additions. Furthermore, the mechanical properties of mortars with treated bottom ash are analysed after different curing times. Finally, the environmental influence of the bottom ash-containing mortar is evaluated through leaching tests.

\section{Materials and methods}

\subsection{Materials and treatments}

The MSWI bottom ash (BA) was provided by a waste-to-energy plant (Attero) in the Netherlands, which has an annual incineration capacity of around 800,000 tons. The grid temperature is about $1000-1300{ }^{\circ} \mathrm{C}$, with 3 separation lines of paper and plastic before the burning of the waste, which will be sent to special factories for reuse. After incineration, the solid residue that comes out from the boiler is quenched in water, followed by the ferrous and nonferrous material removal by electromagnetic and eddy current separation, respectively. After separation, the residue is collected and termed MSWI bottom ash. In this study, the bottom ash fines below $2 \mathrm{~mm}$ (BAF) from the received bottom ash were chosen to be investigated, because of the higher concentration of contaminants compared with coarser particles.

The BAF was milled into powder to reduce its particle size and make it more homogenous using the planetary ball mill. Thermal treatment was performed on the BAF and the milled BAF in the muffle furnace, and the temperatures chosen were $550{ }^{\circ} \mathrm{C}$ and $750{ }^{\circ} \mathrm{C}$, based on the research in Refs. [37,38], the heating capacity of the incinerator, as well as the temperature used to determine the loss on ignition (LOI) [46]. Thermal treatment at $550{ }^{\circ} \mathrm{C}$ was performed on the BAF before and after milling separately to investigate the influence of treatment order on the bottom ash properties.
It is hypothesized that the BA particles are covered by dust-like powders, which contain higher amounts of soluble contaminants, and can have a higher reactivity than the particle itself. In order to separate the fine powder attached on the surface of bottom ash particles for investigation, lower speed and short duration of milling were applied during the milling procedure. The treatments procedure is described as follows:

- Method 1 is to mill the bottom ash using a planetary ball mill with fixed milling duration and speed in order to reduce the particle size to a maximum $125 \mu \mathrm{m}$; the dark-grey powder obtained is labelled as M/BA.

- Method 2 and Method 3 are to thermally treat the milled bottom ash after Method 1 at $550{ }^{\circ} \mathrm{C}$ and $750{ }^{\circ} \mathrm{C}$, respectively; reddishbrown powders are obtained, labelled as M5T/BA and M7T/BA, respectively.

- Method 4 is to heat the bottom ash particles at $550{ }^{\circ} \mathrm{C}$ firstly and then mill them using the same milling procedure as in Method 1, listed as 5TM/BA.

- Method 5 is to mill the thermally treated bottom ash (at $550{ }^{\circ} \mathrm{C}$ ) for a shorter duration and lower speed compared to Method 1, followed by a sieving step to collect the material below $63 \mu \mathrm{m}$ (5TMS/BA); particles above $63 \mu \mathrm{m}$ are labelled as 5TMS+63/BA. Due to the fact that the dust/powder attached on the bottom ash particles could not be removed manually one by one or by machine evenly, the lower speed milling procedure was used in order to remove the attached powder from the particle surface by friction between the particles. The fines bellow $63 \mu \mathrm{m}$ are chosen to be investigated in order to distinguish the powder from the crushed bigger particles during the milling.

The OPC used in this study was CEM I $52.5 \mathrm{R}$ from ENCI HeidelbergCement (the Netherlands) and the sand was CEN normalized sand 0-2 $\mathrm{mm}$ according to EN 196-1 [47].

\subsection{Analysis of material properties}

The chemical compositions of the treated bottom ash and cement were determined by X-ray fluorescence (XRF). The X-ray diffraction (XRD, Cu tube, $40 \mathrm{kV}, 30 \mathrm{~mA}, 3-75^{\circ}, 0.02^{\circ} / \mathrm{step}, 0.2^{\circ} /$ min, variable divergence slits V20) was applied to observe the crystalline phases present in the material.

The particle surface properties of the investigated materials were observed by scanning electron microscope (SEM, Quanta 650 FEG, FEI) and optical microscopy.

The particle size distribution (PSD) of all materials considered in this study was measured by laser diffraction (Mastersizer 2000 Malvern), and a helium pycnometer (AccuPyc II 1340) was used to measure the specific densities.

The amount of metallic aluminium in the treated bottom ash was evaluated with a method measuring the gas volume generated upon the chemical reaction of metallic aluminium with an alkaline solution; the setup for collecting the generated hydrogen is similar to the one described in Ref. [48].

\subsection{Hydration properties study}

The effect of the treated bottom ash on the cement hydration was investigated using an isothermal calorimeter (eight-channel TAM Air, Thermometric). Previous studies on the bottom ash show that its use as cement replacement should be limited under $30 \%$ $[21,25,35]$. Therefore, the treated bottom ash is mixed with cement with the mass ratio of $3: 7$, and the water to binder ratio is kept at 0.7 , to facilitate the loading of the samples into the ampoules. Cement pastes containing different treated bottom ashes were 
cured in water at $20{ }^{\circ} \mathrm{C}$ for 7 days, and subsequently small pieces were extracted from the hardened samples and dried with acetone. The 7 days samples were milled and the crystalline phases were investigated by XRD.

\subsection{Mechanical strength of mortar samples}

The treated bottom ash is pre-mixed with cement in a 3:7 ratio, and the mortar samples were prepared according to EN 196-1 [47]. The flowability of the fresh mortars was determined using the flow table test according to EN 1015-3 [49]. The fresh mortar was cast in $40 \mathrm{~mm} \times 40 \mathrm{~mm} \times 160 \mathrm{~mm}$ prism moulds and demolded after $24 \mathrm{~h}$, and then cured in water at room temperature. The compressive and flexural strengths of mortar samples after different curing ages were tested (AUTOMAX 5). The obtained values were expressed as the averages of three samples.

\subsection{Environmental impact evaluation}

To estimate the environmental impact of the bottom ash before and after the treatments, as well as of the mortars containing bottom ash, leaching tests according to Dutch standard NEN 7383 (2004) [50] were conducted. The mortars containing bottom ash were crushed after 28 days curing to a fraction below $4 \mathrm{~mm}$ for the column leaching test. The liquid to solid ratio for the leaching test is $10 \mathrm{l} / \mathrm{kg}$; the material was placed in a column container and water was forced to flow through the material from the bottom to top for a certain period. The concentration of chemical elements in the eluate was analysed using inductively coupled plasma-atomic emission spectrometry (ICP-AES) according to NEN 6966 [51], and the amount of chloride and sulphate was determined through high performance liquid chromatography (HPLC) following NEN-EN-ISO 10,304-2 [52]. The leaching values of studied elements were compared with the limit value (Table 4) according to the Dutch legislation [53]. The reflux destruction by $\mathrm{HCl} / \mathrm{HNO}_{3}$ on the investigated bottom ash samples were performed according to NEN 6961 [54] and then the concentration of $\mathrm{Cu}$ and $\mathrm{Mo}$ in the extracted solution were determined using inductively coupled plasmaatomic emission spectrometry (ICP-AES) according to NEN 6966 [51]. The amount of Sb was determined using atomic absorption spectroscopy (AAS) according to NVN 7323 [55]; the amounts of chlorides and sulphates were determined according to NEN-EN 1744-5 [56] and NEN-EN 1744-1 [57], respectively.

\section{Results and discussions}

\subsection{Characteristics of materials}

As presented in Fig. 1 (a) and according to the previous study [26], the raw BAF is a fraction with a similar particle size to sand, and has a dark-grey colour. There are quartz particles, iron, glass particles, as well as heterogeneous particles visually observed in bottom ash. Generally these BAF particles are covered by a dust-like layer. It is noticed that after the thermal treatment the colour changed to reddish and iron oxide particles could be observed. The dust-like layer of particles still exists on the surface of the particles, as shown in Fig. 1 (b). According to a previous study [58], after water quenching, the bottom ash particles consist about $60 \%$ particles which were coated by fine particles and other melted phases. This coating on the bottom ash particles results from the reaction occurred during the rapid water quenching process [59], which influence the leaching properties of the bottom ash. After treatment following Method 5, the bottom ash particles under $63 \mu \mathrm{m}$ account for $34.7 \%$ wt. of the milled bottom ash (compared to the initial $2.4 \%$ wt.). The particles above $63 \mu \mathrm{m}$ shown in Fig. 2 have (a)

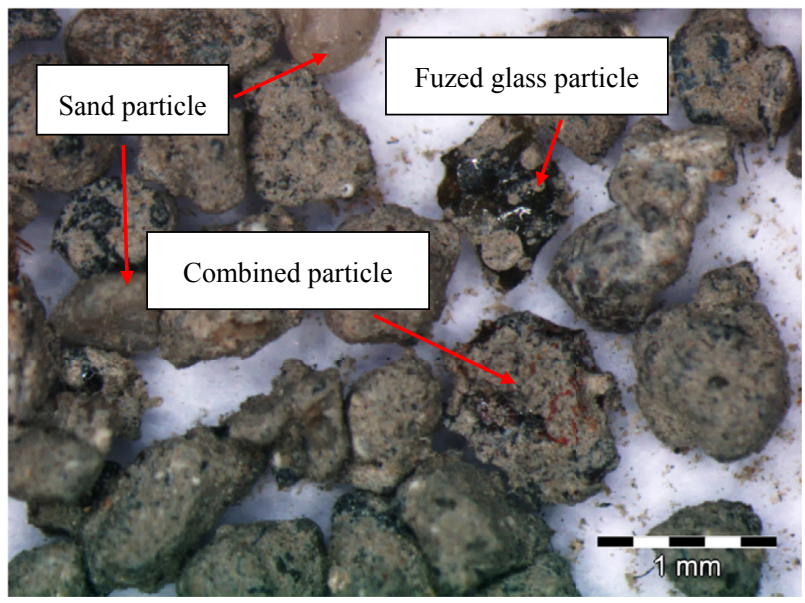

(b)

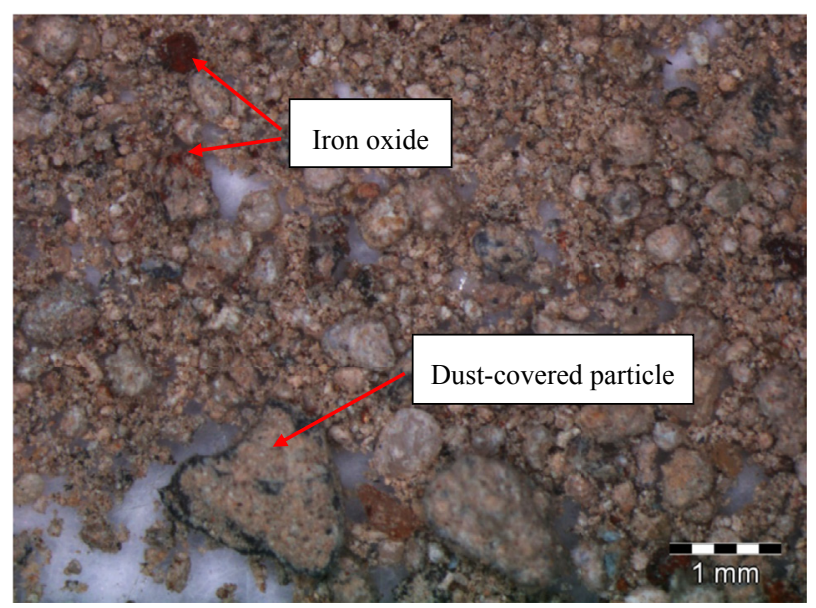

Fig. 1. MSWI bottom ash particles (a) before and (b) after $550{ }^{\circ} \mathrm{C}$ thermal treatment

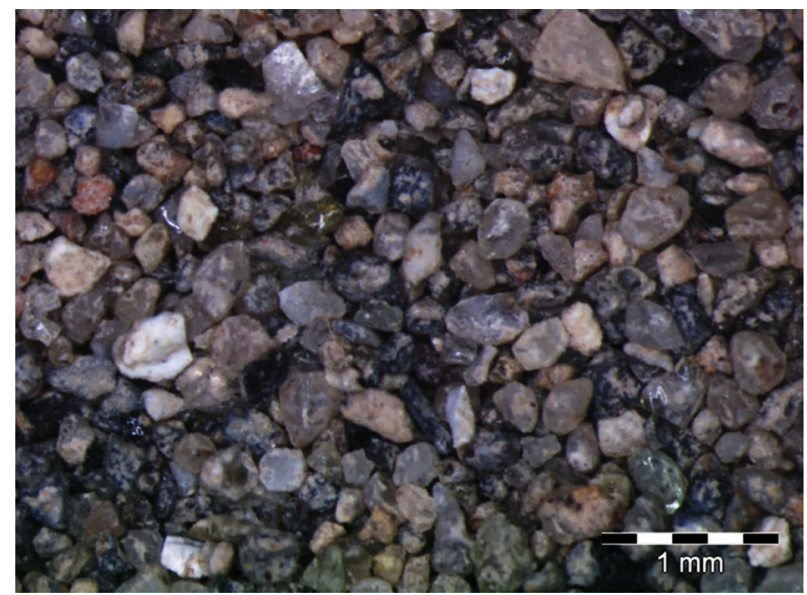

Fig. 2. BAF after treatment following method 5 (particles above $63 \mu \mathrm{m}$ )

relatively cleaner surface than untreated and thermally treated bottom ashes (Fig. 1), as the attached dust-like layers on the surface were partially removed by the friction during milling. Furthermore, these particles are predominantly sand, glass, iron particles, and some plate-shaped metals were also observed (Fig. 3 is shown as an example). 
(a)

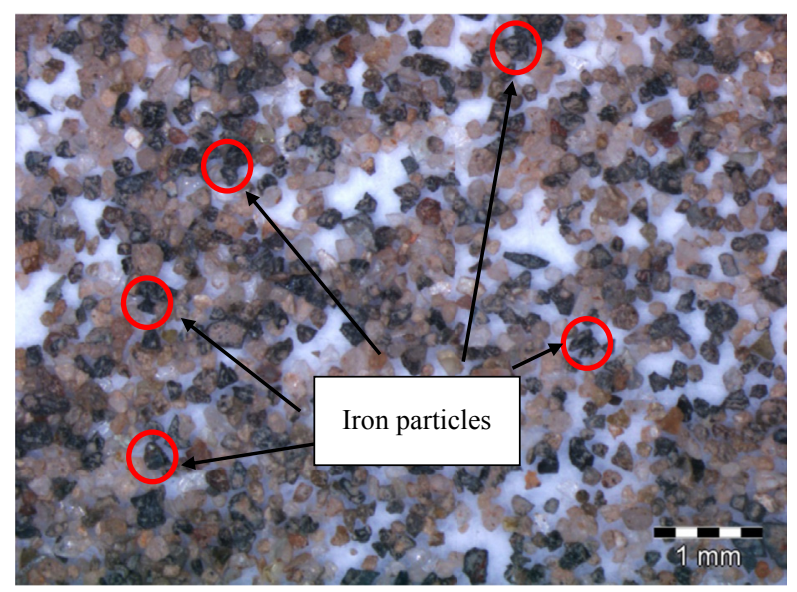

(b)

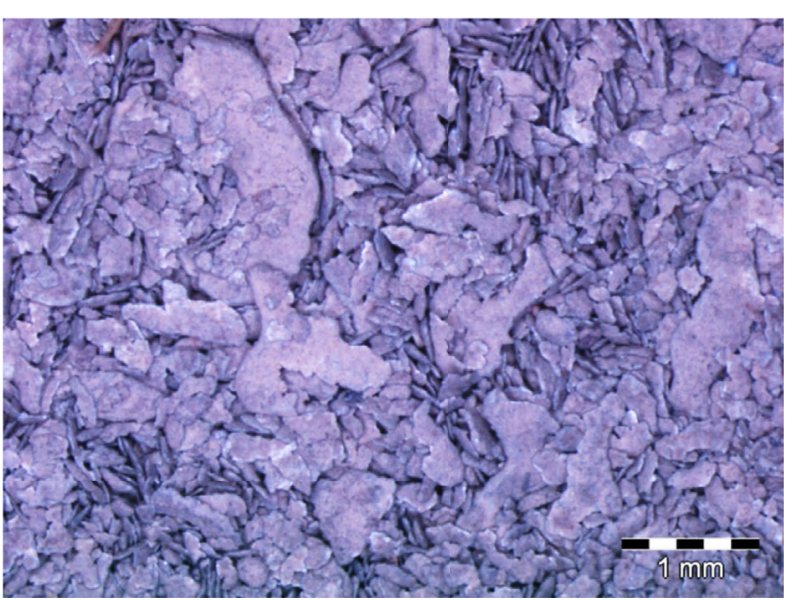

Fig. 3. (a) Iron particles and (b) plate-shaped metals sieved out in bottom ash particles above $180 \mu \mathrm{m}$ after treatment method 5 .

\subsubsection{Chemical properties}

The chemical compositions of the cement and treated bottom ashes are presented in Table 1 . The treated bottom ashes consist of the same main oxides as cement (as assumed by XRF), and their main constituents belong to the $\mathrm{SiO}_{2}-\mathrm{CaO}-\mathrm{Al}_{2} \mathrm{O}_{3}-\mathrm{Fe}_{2} \mathrm{O}_{3}$ system, which in total accounts for about $70 \%-90 \%$ wt. of the bottom ash [35]. However, the treated bottom ashes contain higher amounts of $\mathrm{SiO}_{2}$ and less $\mathrm{CaO}$ than cement, and the content of $\mathrm{Al}_{2} \mathrm{O}_{3}$ and $\mathrm{Fe}_{2} \mathrm{O}_{3}$ is relatively high. A considerable amount of alkali and alkali-earth oxides, such as $\mathrm{Na}_{2} \mathrm{O}$ and $\mathrm{K}_{2} \mathrm{O}, \mathrm{MgO}$ etc. exists in the treated bottom ashes. Similar results are reported elsewhere [22,60].

Comparing the samples M/BA, M5T/BA, M7T/BA, it can be observed that the content of $\mathrm{Cl}$ slightly decreased after the thermal treatment; moreover, the higher temperature leads to a higher decrease of its content. This result is consistent with the finding shown in Refs. [59,61]. In addition, this decrease is more noticeable when the thermal treatment is undertaken after the milling of bottom ash. As reported by Yang et al. [59] the $\mathrm{Cl}$ content is relatively higher in the heterogeneous particles in bottom ash formed during the water quenching procedure, which are unstable under thermal conditions. Therefore, the decomposition of quenched phases in these heterogeneous particles during the heating released the evaporable $\mathrm{Cl}$. Moreover, the organic matter is burnt out during the thermal treatment, thus the organic-associated $\mathrm{Cl}$ [61] is evaporated. Furthermore, the milling increases the particle surface area, leading to the even and efficient heating of the samples, subsequently enhancing the $\mathrm{Cl}$ evaporation from the samples.

As expected, due to the larger specific surface area, the premilling before heating will increase the thermal treatment efficiency, proved by the lower loss on ignition of M5T/BA and M7T/BA than the one of 5TM/BA. In this study the difference between samples which were pre-milled and which were directly thermally treated is quantified through metallic Al content determination and mechanical strength of hardened mortars.

Differently from other treated bottom ash samples in this study, 5TMS/BA has a relatively higher content of $\mathrm{CaO}$ and $\mathrm{Al}_{2} \mathrm{O}_{3}$, and lower content of $\mathrm{SiO}_{2}$ and $\mathrm{Fe}_{2} \mathrm{O}_{3}$. Moreover, its $\mathrm{Cl}$ and $\mathrm{SO}_{3}$ contents are also the highest among all the studied bottom ash samples. According to the literature $[62,63]$, the chemical compositions of MSWI bottom ash differ by size fraction, especially for $\mathrm{Si}_{2} \mathrm{O}$ and $\mathrm{CaO}$. The finer bottom ash particles have a higher content of $\mathrm{SiO}_{2}$ and a lower $\mathrm{CaO}$ content, and this is further confirmed by comparing 5TMS/BA and 5TMS+63/BA. Additionally, the content of $\mathrm{Cl}$ and $\mathrm{SO}_{3}$ is almost 1.5 times of that in other treated bottom ash samples in this study. Also, the dust-like layer removed from the bottom ash particles contains a higher amount of $\mathrm{Cl}$ than the bottom ash particles themselves, which is in line with the findings in

Table 1

Chemical compositions and densities of CEM I 52.5 R, M/BA, M5T/BA, M7T/BA, 5TM/BA, 5TMS/BA and 5TMS+63/BA obtained by XRF.

\begin{tabular}{|c|c|c|c|c|c|c|c|}
\hline Chemical compositions [\% wt.] & CEM I $52.5 \mathrm{R}$ & $\mathrm{M} / \mathrm{BA}$ & M5T/BA & M7T/BA & $5 \mathrm{TM} / \mathrm{BA}$ & 5TMS/BA & $5 \mathrm{TMS}+63 / \mathrm{BA}$ \\
\hline $\mathrm{SiO}_{2}$ & 17.11 & 35.98 & 40.55 & 41.20 & 35.80 & 24.49 & 50.74 \\
\hline $\mathrm{CaO}$ & 64.99 & 19.34 & 19.49 & 20.03 & 21.67 & 28.29 & 16.02 \\
\hline $\mathrm{Al}_{2} \mathrm{O}_{3}$ & 3.80 & 9.00 & 9.44 & 9.82 & 9.93 & 11.07 & 8.64 \\
\hline $\mathrm{Fe}_{2} \mathrm{O}_{3}$ & 3.59 & 11.54 & 11.74 & 12.09 & 12.26 & 8.99 & 13.48 \\
\hline $\mathrm{MgO}$ & 1.56 & 1.81 & 1.97 & 2.09 & 1.99 & 2.26 & 1.92 \\
\hline $\mathrm{Na}_{2} \mathrm{O}$ & 0.00 & 1.35 & 1.49 & 1.89 & 1.48 & 1.37 & 1.59 \\
\hline $\mathrm{K}_{2} \mathrm{O}$ & 0.16 & 1.15 & 0.94 & 1.09 & 1.10 & 1.22 & 1.06 \\
\hline $\mathrm{CuO}$ & 0.02 & 0.43 & 0.50 & 0.53 & 0.55 & 0.65 & 0.48 \\
\hline $\mathrm{ZnO}$ & 0.15 & 0.80 & 0.79 & 0.82 & 0.91 & 1.16 & 0.71 \\
\hline $\mathrm{P}_{2} \mathrm{O}_{5}$ & 0.63 & 1.02 & 1.07 & 1.14 & 1.13 & 1.12 & 1.12 \\
\hline $\mathrm{TiO}_{2}$ & 0.27 & 1.11 & 1.13 & 1.16 & 1.15 & 1.31 & 1.14 \\
\hline $\mathrm{MnO}$ & 0.09 & 0.16 & 0.17 & 0.17 & 0.18 & 0.19 & 0.17 \\
\hline $\mathrm{Cl}$ & 0.02 & 0.66 & 0.64 & 0.56 & 0.74 & 1.06 & 0.43 \\
\hline $\mathrm{SO}_{3}$ & 3.96 & 4.95 & 5.24 & 5.23 & 5.87 & 8.82 & 2.51 \\
\hline Other & 2.01 & 0.69 & 1.19 & 0.71 & 1.31 & 1.10 & a \\
\hline LOI $\left(550^{\circ} \mathrm{C}\right)$ & 0.41 & 7.37 & 2.02 & 1.16 & 2.86 & 2.54 & a \\
\hline $\mathrm{LOI}\left(950^{\circ} \mathrm{C}\right)$ & 1.64 & 9.99 & 3.66 & 1.46 & 3.93 & 6.90 & $\mathrm{a}$ \\
\hline Density $\left[\mathrm{g} \mathrm{cm}^{-3}\right]$ & 3.10 & 2.74 & 2.91 & 2.97 & 2.87 & 2.85 & a \\
\hline
\end{tabular}

a Not measured. 
Refs. $[60,64]$. The fine bottom ash particles have higher amounts of chlorides and sulphates due to the large specific surface and are aggregated on the surface of coarse bottom ash particles during the water cooling procedure, as shown in Fig. 1(a). As also explained in Ref. [58], the newly formed phases on the surface layer during water cooling and weathering enhanced the absorption sites of chloride and sulphate as well. It is commonly known that the fine particles contain higher amount of contaminates due to their large specific area. However, the comparison of 5TMS/BA and 5TMS+63/ BA shows that the finer particles or dust layers sticking on the particle surfaces contribute to the higher amount of contaminants in the BAF. The same trend is observed for heavy metals (details are discussed in Section 3.4). Hence, the prevention of the finer dust sticking on the coarse particle might decrease the content of contaminants in MSWI bottom ash.

Fig. 4 illustrates X-ray diffractograms of the investigated samples. The identified predominant crystalline phases are quartz $\left(\mathrm{SiO}_{2}\right)$, anhydrite $\left(\mathrm{CaSO}_{4}\right)$, calcite $\left(\mathrm{CaCO}_{3}\right)$, hematite $\left(\mathrm{Fe}_{2} \mathrm{O}_{3}\right)$ and magnetite $\left(\mathrm{Fe}_{3} \mathrm{O}_{4}\right)$. The samples after thermal treatment have a relatively higher peak at about $26.6^{\circ}$, which represents the main quartz peak. This result is consistent with the investigation of Qiao et al. [38]. Furthermore, the peak heights corresponding to hematite and magnetite increased, especially in sample M7T/BA. This can be attributed to the fact that heating results in the oxidation of iron in BAF (as shown in Figs. 1 and 3(a)), and higher temperature could enhance this oxidation. It is noticed that the calcite peaks decreased after the $550{ }^{\circ} \mathrm{C}$ thermal treatment, and are not present in sample

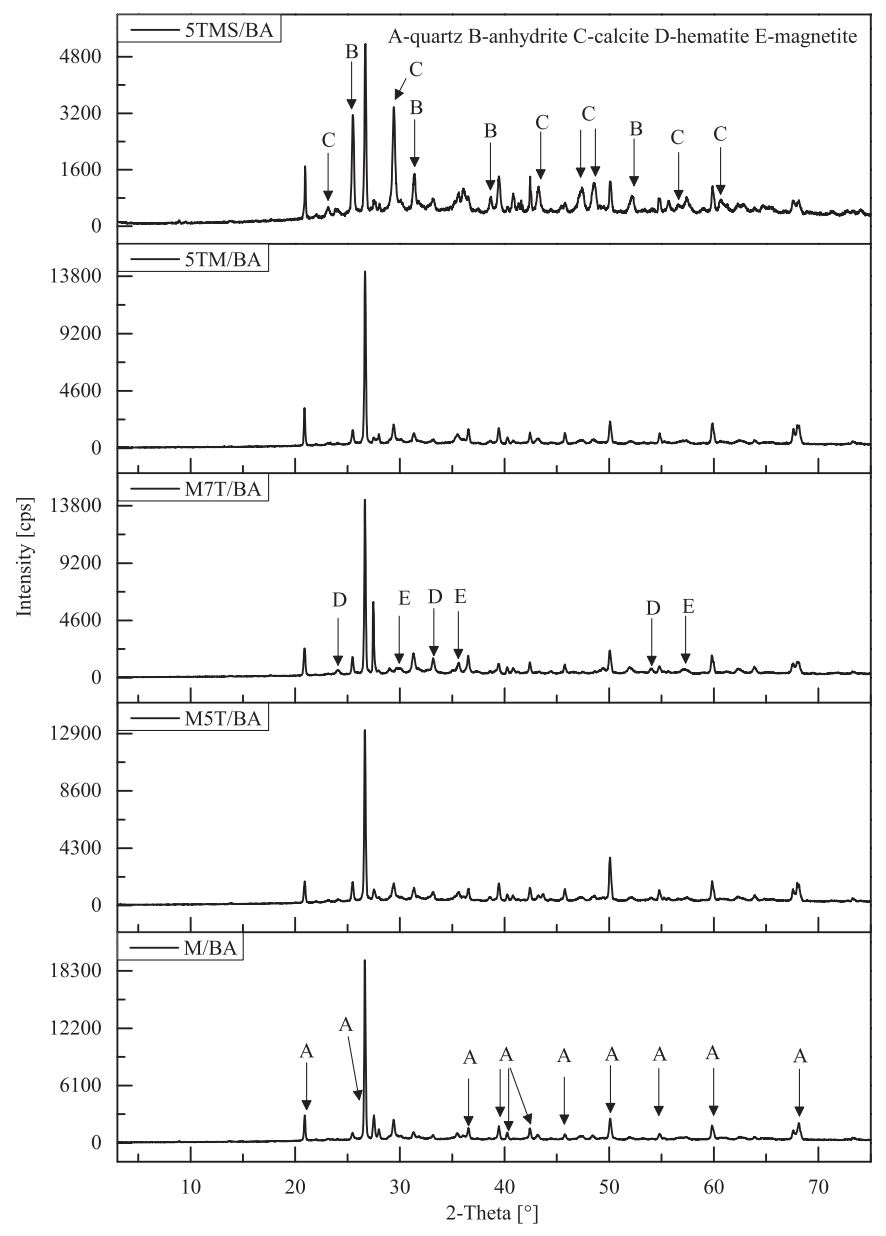

Fig. 4. XRD diffractograms of the treated bottom ash samples.
M7T/BA, which results from the decomposition of calcite at high temperature $[65,66]$.

Qualitatively, no significant differences can be observed between 5TMS/BA, 5TM/BA and M5T/BA in the X-ray diffractrograms. Nevertheless, in 5TMS/BA, the quartz peak height is the lowest, which is in line with the chemical compositions determined in this study (in Table 1, where 5TMS/BA is shown to have $24.5 \% \mathrm{SiO}_{2}$, compared to $35.8 \%$ and $40.5 \%$ for $5 \mathrm{TM} / \mathrm{BA}$ and $\mathrm{M} 5 \mathrm{~T} / \mathrm{BA}$, respectively). In addition, the peaks corresponding to anhydrite $\left(\mathrm{CaSO}_{4}\right)$ and calcite $\left(\mathrm{CaCO}_{3}\right)$ here are much higher than in other samples. Based on the chemical compositions of this sample, it could be concluded that part of the higher amount of the CaO (about 28.3\% compared to $16-21.7 \%$ in other BAF samples in Table 1) can be attributed to the anhydrite $\left(\mathrm{CaSO}_{4}\right)$ and calcite $\left(\mathrm{CaCO}_{3}\right)$, and the high amount of $\mathrm{SO}_{3}$ (about $8.8 \%$ compared to $2.5-5.9 \%$ in other BAF samples in Table 1) can be related to the amount of anhydrite.

To summarize, the BAF mainly contains crystalline phases like quartz, anhydrite, calcite and hematite, and there is no significant change after the $550{ }^{\circ} \mathrm{C}$ thermal treatment. However, higher temperatures (around $750{ }^{\circ} \mathrm{C}$ ) enhance the iron oxidation and decomposition of calcite in BAF. Samples 5TMS/BA, consisting of the fine powder in BAF and the dust-like layer on the particles, possess lower quartz and higher calcite and anhydrite contents and they also contain higher concentration of $\mathrm{Cl}$ and $\mathrm{SO}_{3}$. Hence, a feasible method to prevent or separate the fine powders sticking on the coarse bottom ash particles is an interesting topic.

\subsubsection{Metallic Al}

According to previous research $[30,48,67]$, the metallic $\mathrm{Al}$ in bottom ash can react with an alkaline solution and generate $\mathrm{H}_{2}$, eventually leading to cracks in concrete and high macro porosity in the cement matrix. However, the damage the gas causes in the structure depends on its generation rate and the available amount of metallic $\mathrm{Al}$ in the sample. Hence, in this study, the amount of metallic $\mathrm{Al}$ in the investigated samples is determined. The results are presented in Table 2.

It is apparent that the metallic Al content did not change significantly after the thermal treatment. M7T/BA has slightly less metallic Al than 5TM/BA. This should be due to the fact that the higher temperature enhances the oxidation of the metallic Al.

5TMS/BA contains relatively less metallic Al than all the other investigated samples. This can be due to a numbers of reasons: firstly, the metallic Al in the original bottom ash particles under $63 \mu \mathrm{m}$ is quite easily oxidized during the heating period; secondly, due to the good ductility of the metallic $\mathrm{Al}$, it is deformed into plateshape through the action of the milling balls (as shown in Fig. 3(b)), thus enlarging its surface which consequently could be sieved out. Therefore, to consider the removal and recovery of metallic $\mathrm{Al}$ in the fine bottom ash fraction, special milling equipment should be used, such as an impact mill.

\subsubsection{Physical properties}

Fig. 5 illustrates the SEM images of M5T/BA and 5TMS/BA as examples. It can be seen that most of the treated bottom ash particles have irregular shapes, which is a typical characteristic of the milled bottom ash. Moreover, the surface of the particles has flocculent matter attached to the particles, as reported in Ref. [35].

The specific densities of the samples are shown in Table 1. M/BA

Table 2

Metallic aluminium content of bottom ash samples.

\begin{tabular}{lllll}
\hline Sample & M/BA & 5TM/BA & M7T/BA & 5TMS/BA \\
\hline Metallic Al [\% wt. sample] & 0.44 & 0.48 & 0.46 & $<0.2$ \\
\hline
\end{tabular}


(a)

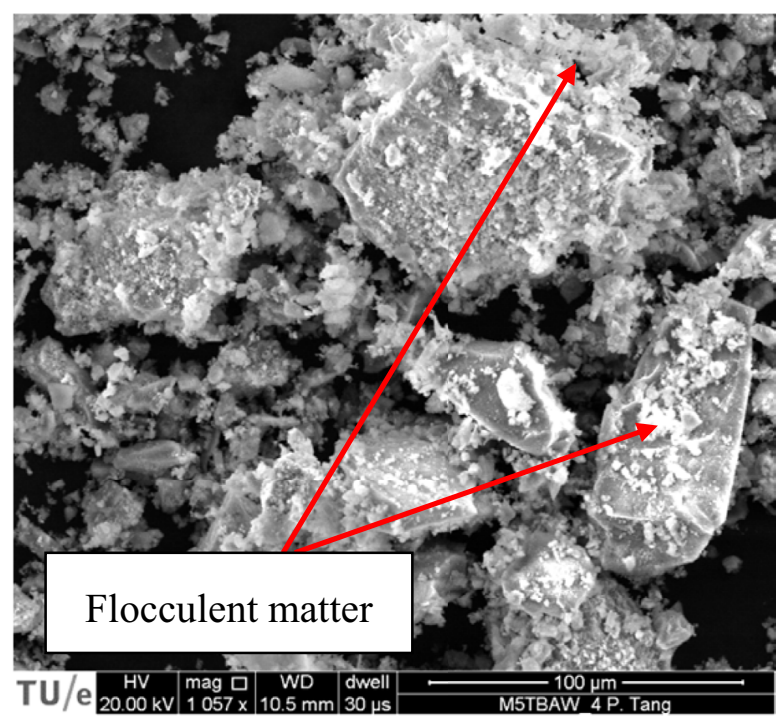

(b)

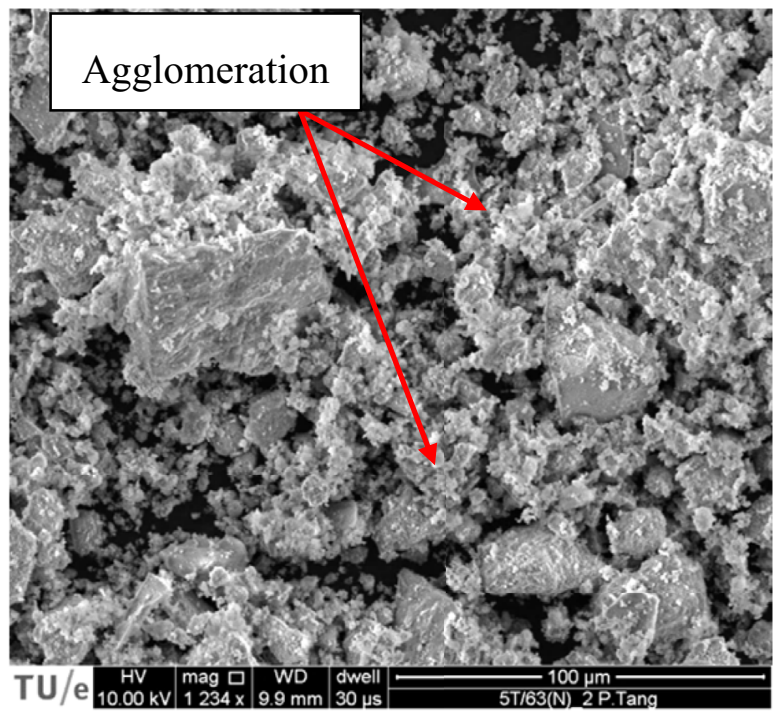

Fig. 5. SEM images of (a) M5T/BA and (b) 5TMS/BA.

has a slightly higher density than normal sand which is about $2.65 \mathrm{~g} / \mathrm{cm}^{3}$. This is due to the fact that there are metal and ceramic particles in the BAF which could not be separated completely. The densities of thermally treated bottom ash increased. Moreover, a higher treatment temperature results in a higher density. The variation of the density after thermal treatment can be attributed to the combined effect of two opposing processes: burning the organic matter and the oxidation of the metals. The density of 5TMS/BA is lower than other thermally treated samples in this study, which could be due to the removal of iron and quartz particles during sieving (Fig. 3), as previously explained.

Fig. 6 presents the particle size distribution of the analysed materials. It can be observed that all the samples are coarser than cement powder, 5TM/BA excepted. Moreover, the thermal treatment on milled samples results in a coarse particle size, which is due to the agglomeration of fine particles during the thermal treatment [48]. In addition, the flocculent matter on the particles contributes partly to this phenomena (Fig. 5(a)). According to the measured PSD, sample 5TMS/BA has coarser particles compared

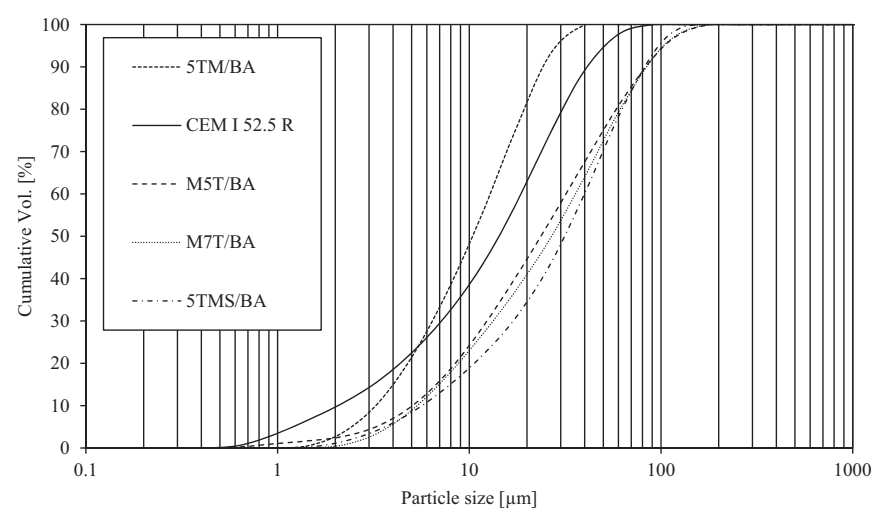

Fig. 6. The particle size distributions (PSDs) of the investigated materials.

with other bottom ash samples analysed in this study. However, this is a surprising result, because the 5TMS/BA only contains particles passing the $63 \mu \mathrm{m}$ sieve. This could be because of the agglomeration of the powder (Fig. 5(b)), which in turn can be caused by the electrostatic interaction of particles.

To summarize, the order of milling and thermal treatment affects the particle size distribution of the samples. The high temperature of the thermal treatment on BAF contributes to the decomposition of calcite. Moreover, short time and a lower speed milling process, plus sieving, could reduce the metallic aluminium content in the chosen sample.

\subsection{Hydration properties of bottom ash-cement mixes}

In order to evaluate the influence of the thermally treated bottom ash samples and their contribution to the cement hydration, the heat development of cement with treated bottom ash (BA) during the hydration process are studied by isothermal calorimetry. The heat evaluation of the BA-cement mix, which is calculated on the basis of the total powder mass (cement and treated or untreated bottom ashes), is depicted in Fig. 7.

The hydration process of cement is typically divided into four periods, namely the initial stage, induction stage, acceleration stage and deceleration stage. Fig. 7(a) shows the heat flow of the investigated samples. It can be seen that the samples with treated or untreated bottom ashes have lower second maximum heat release rates (SMHR) than plain cement, while their SMHR are higher than $70 \%$ of the plain cement value. This indicates that the $30 \%$ bottom ash addition cannot be comparable to $30 \%$ of pure cement; however, they do contribute to the cement hydration to a certain degree. There is no difference in the aspect of the calorimetric curves of plain cement paste and BA-cement mixes (Fig. 7(a)). However, the additions of M/BA to cement lead to the retardation of cement hydration, so that the second maximum heat release rate (SMHR) is reached over three hours later than that of the cement paste (Table 3). For samples with 5TM/BA, this retardation is reduced by around $50 \mathrm{~min}$, and the maximum heat release rate is higher than that of $70 \%$ of the plain cement and cement with sample M/BA. This means that the 5TM/BA has a more beneficial effect on the advancement of cement hydration than the M/BA samples. For samples with M5T/BA and M7T/BA, the maximum heat release rate is reached slightly earlier than in the case of plain cement. It can be noticed in Table 3 that the time needed for reaching the maximum heat release rate after the acceleration period of cement hydration, has a similar trend with that of the loss on ignition of the bottom ash samples at $550{ }^{\circ} \mathrm{C}$. The retardation effect of bottom ash on the cement hydration could be attributed to the organic matter 
(a)

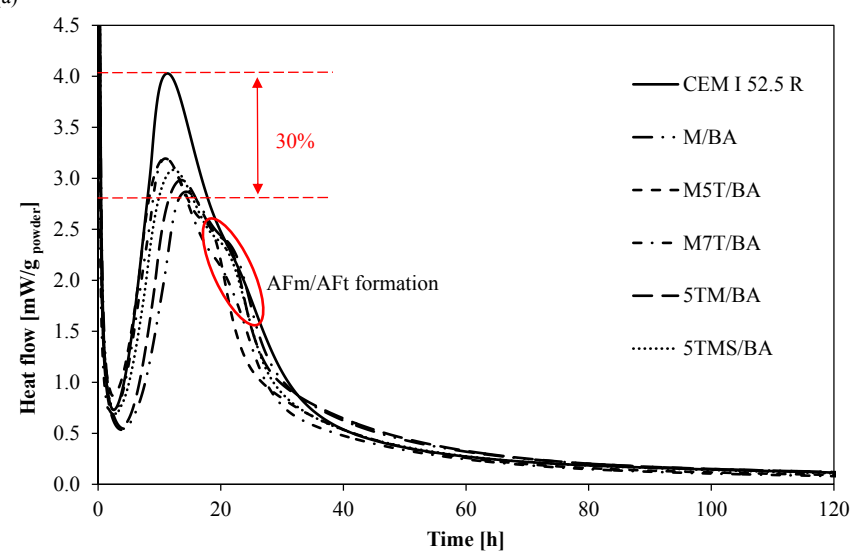

(b)

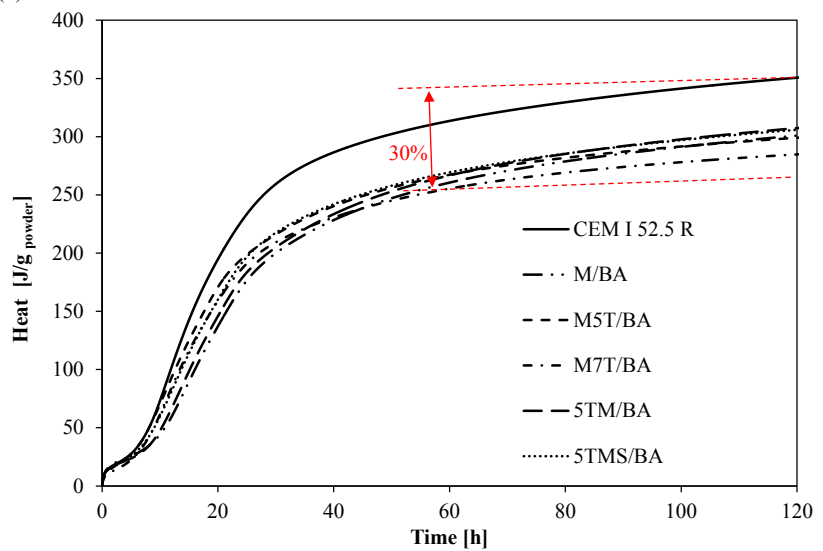

Fig. 7. The heat flow (a) and released heat (b) of cement with treated bottom ash relative to total powder amount. again [73]. Therefore, in Fig. 7, the shoulder for pure cement at 22-27 h represents the formation of AFm. In the XRD pattern shown in Fig. 8 on the hydrated cement paste, the AFm phase is found, which also confirms this.

For the samples with ashes, there are several possibilities related to the sulphate consumption reaction. Firstly, the anhydrite in the ashes provides sulphates for the hydration of $C_{3} A$ in the cement, which may result in more AFt formation [73]; secondly, the sulphate in the ashes does not have an influence on the reaction of $\mathrm{C}_{3} \mathrm{~A}$, which means there will be AFm or little AFt found in the cement hydrates; thirdly, the sulphate in the ashes is a new resource for converting the AFm further to form AFt. Hence, the amount, dissolving rate and the type of the sulphate in the ashes are important parameters for its role in the cement reaction [74-77]. Therefore, the 'shoulder' for the samples with ashes could be attributed to the formation of AFt or AFm, which is mainly related to sulphate consumption during the cement hydration.

Fig. 7(b) and Table 3 show that the samples with bottom ashes achieved a lower total heat released based on the total mass of powder contents after the same hydration duration; their total heat released is however still higher than $70 \%$ of the plain cement value. The highest total heat (beside the plain cement sample) is reached by samples with 5TM/BA, followed by 5TMS/BA. It can be seen from the XRD pattern (Fig. 8) of the hydrated samples with and without ashes that there is AFm found in samples of plain cement, M5T/BA and M7T/BA. However, for the other samples with ashes, there is no AFm or AFt found. Considering the calorimeter results together, it can be explained that the samples with M5T/BA and M7T/BA may provide extra sulphate for cement to form AFm as explained above. For the other samples with ashes, the shoulder can be attributed to the second formation of AFt from AFm because of newly available sulphate; hence, these samples release a higher amount of heat during the cement hydration after 7 days than only $70 \%$ cement. Also, due to the consumption of the AFm and poor crystalline structure of AFm [78], there is no AFm or AFt found in the XRD

Table 3

Calorimetric parameters of cement hydration and LOI of the investigated samples.

\begin{tabular}{|c|c|c|c|c|c|c|}
\hline & CEM I $52.5 \mathrm{R}$ & $\mathrm{M} / \mathrm{BA}$ & $5 \mathrm{TM} / \mathrm{BA}$ & M5T/BA & M7T/BA & 5TMS/BA \\
\hline SMHR [hour] & 11.31 & 14.38 & 13.55 & 10.92 & 10.98 & 12.31 \\
\hline Maximum heat release rate $\left[\mathrm{mW} / \mathrm{g}_{\text {cem }}\right]$ & 4.03 & 2.87 & 2.98 & 3.20 & 3.19 & 3.08 \\
\hline Total heat after $168 \mathrm{~h}\left[\mathrm{~J} / \mathrm{g}_{\mathrm{cem}}\right]$ & 366.65 & 317.21 & 323.35 & 311.07 & 295.53 & 319.98 \\
\hline LOI $550{ }^{\circ} \mathrm{C}[\% \mathrm{wt}]$. & 0.41 & 7.37 & 2.86 & 2.02 & 1.16 & 2.54 \\
\hline
\end{tabular}

SMHR: duration for reaching the second maximum heat release rate.

contained in the bottom ash [68-70]. After the thermal treatment at this temperature, the organic matter is burned out, thus the retardation effect is reduced.

During the deceleration stage, there is a 'shoulder' on the hydration curve of samples with bottom ashes at around 17-25 h. A similar 'shoulder' can also be observed on the net cement hydration curve during the deceleration stage at around 22-27 h; however, this 'shoulder' is not clearly visible compared to the samples with bottom ashes.

According to [71,72], this 'shoulder' represents the formation of the AFm phase in pure cement paste. During cement hydration [72], the calcium aluminate $\left(\mathrm{C}_{3} \mathrm{~A}\right)$ reacts with calcium sulphate to form ettringite (AFt); after the calcium sulphate is completely consumed, due to the decrease of sulphate ions in the pore solution, the unstable ettringite converts to monosulphate; this normally occurs after 1 day or 2 days after the mixing of the cement paste; when there is a new source of sulphate ions come to be available in the pore solution, then the monosulphate reacts to form ettringite pattern of these samples.

Nevertheless, the hydration of cement is influenced by the organic content, the water to cement ratio, sulphate content, particle size and surface area, etc.; thus, the results should not only be explained by a single parameter. However, the total released heat results indicate that the addition of bottom ashes partially contribute to the cement hydration. Moreover, the retardation effect on cement hydration might be reduced by heating the milled bottom ash samples.

\subsection{Mortar properties}

As previous research reported [79], the lower pozzolanic properties of BAF and its retardation effect on cement hydration limit the amount to be used as cement replacement. Hence, based on literature, the replacement ratio of cement by treated bottom ashes is fixed at $30 \%$ in this study. The standard mortars are prepared according to EN 196-1 [47], and the fresh and hardened states 
(a)

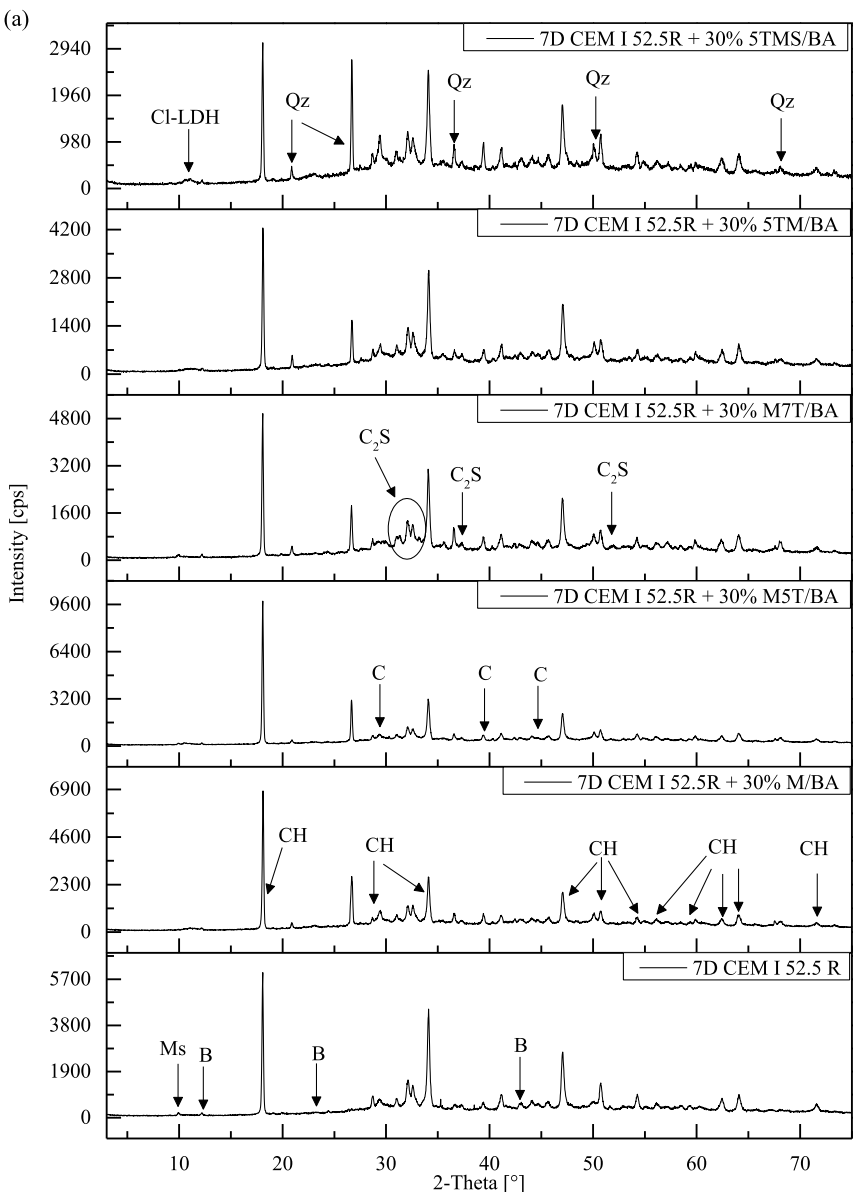

(b)

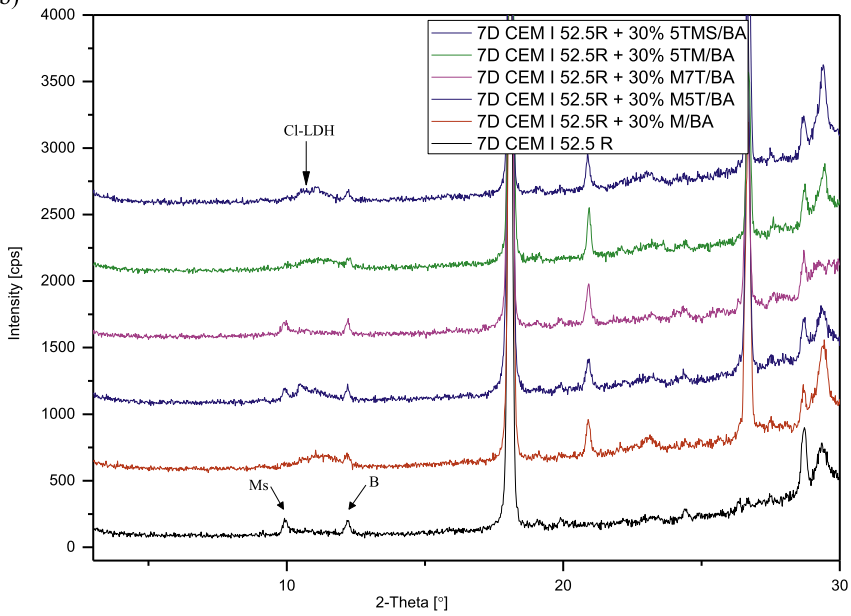

Fig. 8. XRD diffractograms of the cement pastes with bottom ashes after 7 days hydration (a) $3-75^{\circ}$ (b) $3-30^{\circ}$ (Ms - monosulphate, B-brownmillite, C-calcite, $\mathrm{CH}$-portlandite, Qz-quartz, $\mathrm{C}_{2} \mathrm{~S}$-dicalcium silicate phase, $\mathrm{Cl}$-LDH-chloride layered double hydroxide).

properties are tested. The results are shown in the following section.

\subsubsection{Flowability of mortars with treated bottom ashes}

The test results show that the flowability of mortar decreases when treated bottom ash is added, except for the sample with M/BA (175 mm, compared with $170 \mathrm{~mm}$ of the reference). 5TMS/BA leads to the lowest flowability $(160 \mathrm{~mm})$, and M7T/BA leads to a higher flowability $(169 \mathrm{~mm})$ than M5T/BA $(165 \mathrm{~mm})$. However, the quantitative differences on the flowability of the mortars are not significantly affected by adding the treated bottom ashes.

It is commonly known that the particle size distribution, particle shape, as well as particle texture of the alternative powder influence the water demand and subsequently the flowability of fresh mortar $[35,80]$. Hence, according to the previous investigations shown in this study (Figs. 5 and 6), these complex influential factors contribute to the phenomenon observed here.

\subsubsection{Compressive and flexural strength}

The compressive and flexural strengths of mortars containing bottom ash additions after various curing ages are displayed in Figs. 9 and 11.

It is demonstrated that both the compressive and flexural strengths of all the samples decrease at all curing ages [35]; when the treated bottom ash is applied, the mortar with 5TMS/BA gains higher strength than other bottom ash-containing samples. Moreover, for all the samples, the decrease of the flexural strength is not as significant compared to the reduction of the compressive strength.

For all the investigated samples, the compressive strength increases with increasing curing age. Furthermore, their differences to the reference are reducing with longer curing ages. It is noticed that the mortar with 5TM/BA gains higher compressive strength at all curing ages than the mortar with M/BA. This is attributed to the burning of organic matter in the BAF at $550{ }^{\circ} \mathrm{C}$, which decreases its detrimental effect on cement hydration. Additionally, after 28 days curing, the decrease of compressive strength of the mortar with $\mathrm{M} /$ BA is about $36 \%$, but only about $30 \%$ in case of the mortar with $5 \mathrm{TM} /$ $\mathrm{BA}$, indicating the detrimental influence of M/BA and 5TM/BA. This is in agreement with the finding presented in Section 3.2.

However, the strength test results for the mortar with M5T/BA and M7T/BA are in conflict with the calorimetry results. These mortars have a relatively higher decrease of the compressive strength at all curing ages than other samples. For instance, after 28 days the compressive strength of mortars with M5T/BA and M7T/ BA is about $30 \mathrm{MPa}$ and $37 \mathrm{MPa}$, respectively (51\% and 40\% decrease compared to the reference, respectively). Their strength is even lower than mortar with M/BA. This higher reduction should be due to the inner cracks in mortars (as shown in Fig. 10) created by the $\mathrm{H}_{2}$ generated upon the hardening of mortar. Nevertheless, inner cracks [67] are not found in mortars with M/BA, 5TM/BA and 5TMS/BA, of

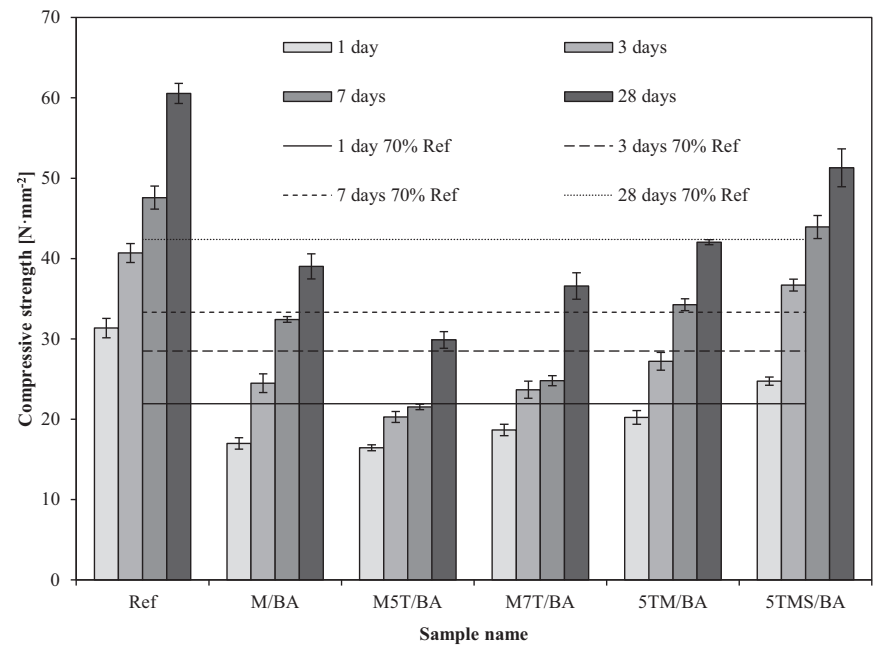

Fig. 9. Compressive strength of mortar containing bottom ash after $1,3,7,28$ days curing and the calculated $70 \%$ of reference lines. 

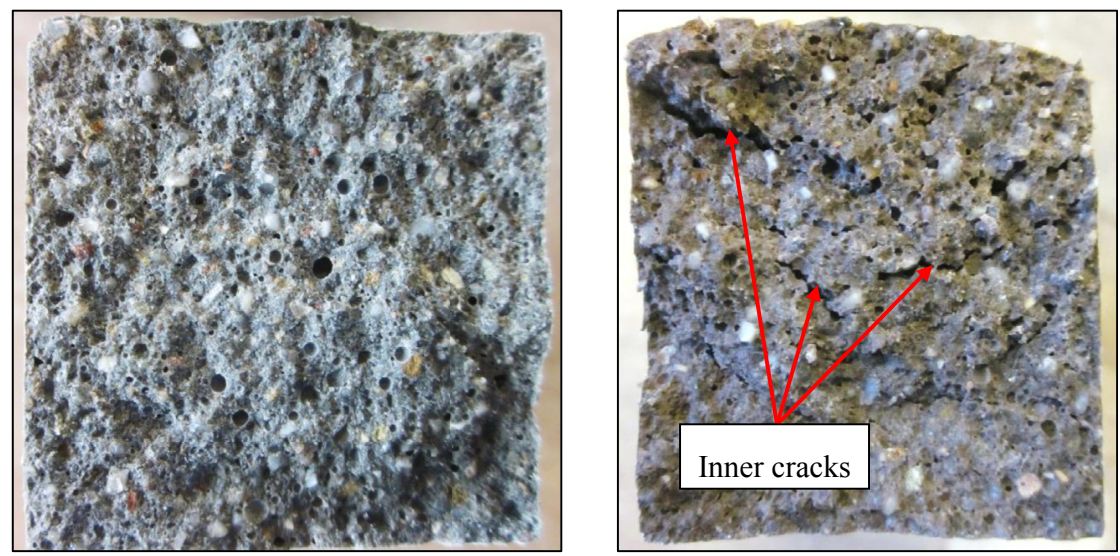

Fig. 10. The fracture surface of mortars (reference and M5T/BA).

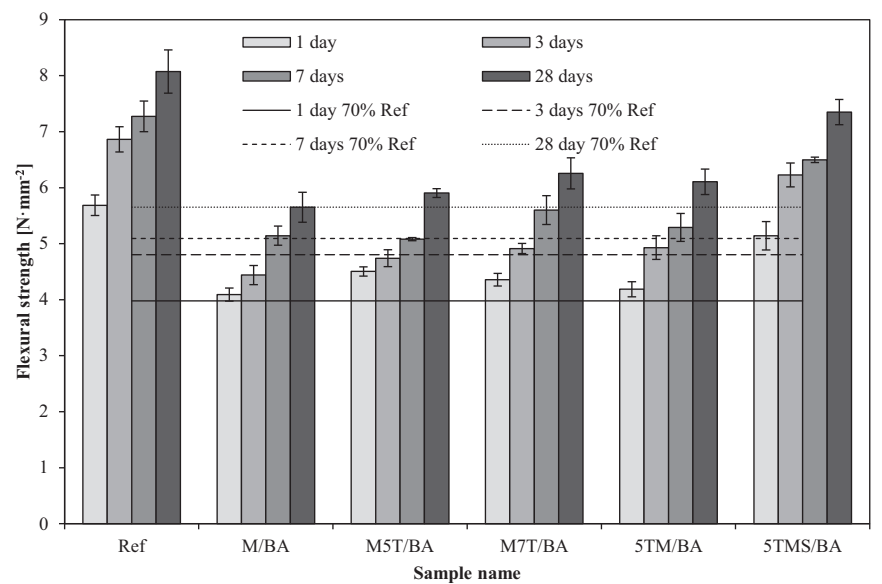

Fig. 11. Flexural strength of mortars containing bottom ash after 1, 3, 7, 28 days curing and the calculated $70 \%$ of reference lines.

which the first two have similar contents of metallic Al. This could be explained as follows: the thermal treatment on the milled bottom ash powder is more efficient on burning out the organic matter, as well as the oxidation of metallic aluminium. Hence, after thermal treatment, the surface of the metallic Al particles is oxidized [81]. Subsequently the reaction between metallic Al and alkalis takes a longer time, and the gas generated later could not be released before the hardening of mortar. Eventually, inner cracks form, which reduce dramatically the strength of mortar.

Mortar with 5TMS/BA gains the highest 28-day compressive strength, about $51 \mathrm{MPa}$, a 15\% reduction compared to the reference. This result should be due to the following reasons: firstly, the particle size of the 5TMS/BA is controlled under $63 \mu \mathrm{m}$, which leads to a denser microstructure of the mortars. Secondly, it has the lowest metallic Al content in comparison with other treated bottom ash samples, so in turn less inner cracks are generated. Thirdly, it has a lower content of $\mathrm{SiO}_{2}$ and a higher amount of $\mathrm{CaO}$, which may participate in the cement hydration process.

The flexural strength of the mortar decreases when using bottom ash samples; however, the effect of the treated bottom ash on the flexural strength is more complicated than for the compressive strength. The flexural strength is significantly influenced by the cement hydration [82], and irregular particle shapes have a positive effect on flexural strength $[83,84]$. As the bottom ash has lower pozzolanic properties and more irregularly-shaped particles, part of the inert particles act as filler in the mortar matrix. Hence, there is a better inter-locking effect between the cement paste and these particles, which contributes to a lower reduction of the flexural strength (Fig. 11). This finding is consistent with results reported by other researchers $[85,86]$.

To summarize, the cement blended with $30 \%$ by M/BA can be used to produce low strength mortar, its compressive strength is comparable with that reported previously [35]. The cement with $30 \%$ 5TMS/BA could be used to produce a standard mortar which has a 28-day compressive strength of $51 \mathrm{MPa}$ (compared to the $61 \mathrm{MPa}$ reference).

\subsection{Environmental impact evaluation}

According to the Dutch legislation (Soil Quality Decree, SQD) [53], the leaching concentration of heavy metals and salts should be below the limiting values, considering the environmental impact and human health. The column leaching test is performed on the treated bottom ash samples, as well as on the mortar with treated samples to evaluate their environmental impact. The results are shown in Table 4.

Based on the evaluation of ten-year leaching data on the MSWI bottom ash in the previous work of the authors [26,87], it was summarized that the leaching concentration of most elements in the bottom ash from this plant is below the limits and the leaching of antimony $(\mathrm{Sb})$, copper $(\mathrm{Cu})$, molybdenum (Mo), chloride $\left(\mathrm{Cl}^{-}\right)$ and sulphate $\left(\mathrm{SO}_{4}^{2-}\right)$ mostly exceed the limit level. Hence, the leaching after the treatment is evaluated in this study and their total amount in the treated and untreated ashes are measured as well (Table 4).

It is indicated in Table 4 that the leaching of $\mathrm{Sb}$ and $\mathrm{Cu}$ in the bottom ash without thermal treatment exceeds the limit values (more than 4 times of the limit emission value). However, after the thermal treatment, their leaching concentration reduced significantly and is well under the limiting level. This could be due to the burning of the organic matter, which is related to the leaching of copper [88-90]. It can be seen that M/BA and 5TMS/BA have the same amount of $\mathrm{Cu}$, however, $\mathrm{M} / \mathrm{BA}$ has a higher leaching of $\mathrm{Cu}$. This confirms that the thermal treatment decreases the leaching of $\mathrm{Cu}$. Sample 5TM/BA has a higher total amount of Cu than 5TMS/BA, but lower leaching of $\mathrm{Cu}$ than 5TMS/BA. This is due to the fact that 5TMS/BA has more soluble $\mathrm{Cu}$, which is mainly absorbed during the quenching process. 5TMS/BA, which concentrated the most contaminated fine powder in BAF, has a relatively higher leaching of $\mathrm{Mo}, \mathrm{Cl}^{-}$and $\mathrm{SO}_{4}^{2-}$, which is in line with the finding in Refs. [58,59] that the dust-layer on the particle surface influences the contaminant leaching. In the case of Mo and Sb, the variation in leaching 
Table 4

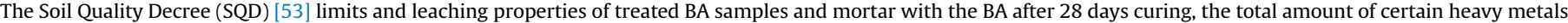
and salts (d.s.-dry solid) and the $\mathrm{pH}$ of the leachate after column leaching of same samples.

\begin{tabular}{|c|c|c|c|c|c|c|c|c|c|c|}
\hline & \multirow[t]{2}{*}{ SQD limit value [53] } & \multicolumn{3}{|c|}{ Total amount [mg/kg d.s.] } & \multicolumn{6}{|c|}{ Leaching value [mg/kg d.s.] } \\
\hline & & $\mathrm{M} / \mathrm{BA}$ & $5 \mathrm{TM} / \mathrm{BA}$ & 5TMS/BA & $\mathrm{M} / \mathrm{BA}$ & 5TM/BA & 5TMS/BA & Mortar with M/BA & Mortar with 5TM/BA & Mortar with 5TMS/BA \\
\hline $\mathrm{Sb}$ & 0.16 & 75 & 86 & 110 & 0.79 & 0.037 & 0.023 & $<0.0089$ & $<0.0059$ & $<0.0089$ \\
\hline $\mathrm{Cu}$ & 0.9 & 3100 & 4000 & 3100 & 3.6 & $<0.050$ & 0.3 & 0.17 & $<0.050$ & 0.06 \\
\hline Mo & 1 & 11 & 10 & 12 & 0.67 & 1.4 & 2.6 & 0.09 & 0.11 & 0.092 \\
\hline $\mathrm{Cl}^{-}$ & 616 & 3800 & 5300 & 9200 & 4400 & 3300 & 6600 & 350 & 290 & 450 \\
\hline $\mathrm{SO}_{4}^{2-}$ & 1730 & 18,100 & 24,000 & 45,700 & 16,000 & 20,000 & 23,000 & 180 & 180 & 270 \\
\hline $\mathrm{pH}$ & & a & a & a & 7.8 & 10.39 & 10.18 & a & a & a \\
\hline
\end{tabular}

a Not measured.

can be attributed to the change in $\mathrm{pH}$ of the leachate. The $\mathrm{pH}$ data of the leachate of each sample is mentioned in Table 4. It can be seen that the samples that underwent thermal treatment will generate a much higher leachate $\mathrm{pH}$. This difference explains both the decrease of Sb leaching and the increase of Mo leaching [41,44]. The chloride leaching of 5TM/BA is lower than that of $\mathrm{M} / \mathrm{BA}$, which confirms the removal of the highly soluble chlorides by the thermal treatment [59]. However, this reduction is not remarkable and the leaching is still above the limit level. The leaching of sulphates from the investigated samples exceeds the limit value of the legislation, and it seems thermal treatment did not influence the leaching of sulphate significantly.

The leaching properties of the mortars with treated bottom ash samples are also studied to investigate the immobilization of the contaminants in the samples. It can be seen in Table 4 that the leaching of all the investigated heavy metals and the salts is far below the limit leaching level. Hence, the mortars with 30\% cement replacement by the treated bottom ash meet the Dutch legislation [53]. Moreover, the sulphate is more immobilized than the chloride in the mortar, when comparing their total amount and leached concentration (Table 4). This may further prove that the sulphate in bottom ash participates in the cement reaction as explained in Section 3.2, hence the leaching of sulphate in the mortar decreases more than that of chloride.

Consequently, in this study the leaching of $\mathrm{Sb}$ and $\mathrm{Cu}$ of the BAF is reduced to values under the limit by thermal treatment. Furthermore, the mortar with treated bottom ash complies with the Dutch national environmental legislation [53] considering the leaching of contaminants in future life cycles.

\section{Conclusions}

In this study, milling and thermal treatment are applied to upgrade the properties of fine MSWI bottom ash $(0-2 \mathrm{~mm})$, and the characteristics of the treated bottom ashes are investigated. Moreover, their effect on cement hydration and mortar properties containing $30 \%$ bottom ashes as cement replacement are illustrated. The following conclusions can be drawn:

(1) The main chemical components of the MSWI bottom ash are $\mathrm{SiO}_{2}, \mathrm{CaO}, \mathrm{Al}_{2} \mathrm{O}_{3}, \mathrm{Fe}_{2} \mathrm{O}_{3}$ and the main crystalline phases are quartz, calcite, anhydrite and hematite. After the thermal treatment at $550{ }^{\circ} \mathrm{C}$ and $750{ }^{\circ} \mathrm{C}$, qualitative differences on the chemical compositions are not identified. Higher temperature results in the decomposition of calcite and enhances the oxidation of iron. The amount of metallic $\mathrm{Al}$ is not reduced significantly after the thermal treatment. However, the short time and lower speed milling followed by sieving can separate the metallic Al from the fine powder chosen for the investigation. Additionally, this fine powder has a lower amount of $\mathrm{SiO}_{2}$ and higher amount of $\mathrm{CaO}$ and $\mathrm{Al}_{2} \mathrm{O}_{3}$.
(2) The hydration of the cement is retarded when milled raw BAF is added, which is due to the organic matter and heavy metals. Thermal treatment can reduce the retardation effect of the bottom ash on cement hydration. Furthermore, a sufficient thermal treatment on milled bottom ash enhances the contribution of the bottom ash on cement hydration and minimizes its retardation effect. The sulphate content in the bottom ash accelerates the hydration of $\mathrm{C}_{3} \mathrm{~A}$ and then increases the formation of AFm during the deceleration stage of cement hydration.

(3) The 28-day compressive strength of the mortar with $30 \%$ treated bottom ashes replacement is $30-51 \mathrm{MPa}$, which is less than the reference (61 MPa). The highest strength is obtained in mortar with 5TMS/BA; the 30\% cement replacement results in 15\% compressive strength and $8 \%$ flexural strength reduction. Although an efficient thermal treatment increases the contribution of bottom ash on cement hydration, the oxidation of metallic $\mathrm{Al}$ prolongs the generation of gas. Eventually, the cracks in the hardened mortar reduce its strength.

(4) Thermal treatment efficiently reduces the leaching of Sb and $\mathrm{Cu}$, and slightly decreases the chloride leaching of the bottom ash fines. The mortars with $30 \%$ treated bottom ashes are environmentally acceptable according to the Dutch legislation, as the leaching of heavy metals and salts is well under the limit level. The fine dust-layers removed from the bottom ash particles have higher leaching levels of heavy metals, which confirms that these layers influence the heavy metals leaching of MSWI bottom ash.

(5) The technique for the removal of metallic Al by slow milling (and the formation of metal plates which can be sieved out) was proposed and its applicability was proven.

\section{Acknowledgement}

The authors gratefully thank the China Scholarship Council (China) and the Department of the Built Environment, Eindhoven University of Technology (the Netherlands) for supporting this research. We would like to thank Dipl. Min. K. Schollbach for help on the XRD identification. The authors wish to express their gratitude to the sponsor company - Attero - and to the following sponsors of the Building Materials research group at TU Eindhoven: Rijkswaterstaat Grote Projecten en Onderhoud, Graniet-Import Benelux, Kijlstra Betonmortel, Struyk Verwo, ENCI HeidelbergCement, Rijkswaterstaat Zee en Delta-District Noord, Van Gansewinkel Minerals, BTE, V.d. Bosch Beton, Selor, GMB, Geochem Research, Icopal, BN International, Eltomation, Knauf Gips, Hess AAC Systems, Kronos, Joma, CRH Europe Sustainable Concrete Centre, Cement\&BetonCentrum, Heros, and Inashco (in chronological order of joining). 


\section{References}

[1] M. Uwasu, K. Hara, H. Yabar, World cement production and environmental implications, Environ. Dev. 10 (2014) 36-47.

[2] M. Schneider, M. Romer, M. Tschudin, H. Bolio, Sustainable cement production-present and future, Cem. Concr. Res. 41 (2011) 642-650.

[3] T. Xu, T. Galama, J. Sathaye, Reducing carbon footprint in cement material making: characterizing costs of conserved energy and reduced carbon emissions, Sustain. Cities Soc. 9 (2013) 54-61.

[4] E. Tkaczewska, R. Mróz, G. Łój, Coal-biomass fly ashes for cement production of CEM II/A-V 42.5R, Constr. Build. Mater. 28 (2012) 633-639.

[5] C. Berryman, J. Zhu, W. Jensen, M. Tadros, High-percentage replacement of cement with fly ash for reinforced concrete pipe, Cem. Concr. Res. 35 (2005) 1088-1091.

[6] M. Antoni, J. Rossen, F. Martirena, K. Scrivener, Cement substitution by a combination of metakaolin and limestone, Cem. Concr. Res. 42 (2012) 1579-1589.

[7] R. Siddique, R. Bennacer, Use of iron and steel industry by-product (GGBS) in cement paste and mortar, Resour. Conserv. Recycl. 69 (2012) 29-34.

[8] K.L. Lin, D.F. Lin, Hydration characteristics of municipal solid waste incinerator bottom ash slag as a pozzolanic material for use in cement, Cem. Concr. Compos. 28 (2006) 817-823.

[9] A. Cheng, Effect of incinerator bottom ash properties on mechanical and pore size of blended cement mortars, Mater. Des. 36 (2012) 859-864.

[10] T.-C. Lee, C.-J. Chang, M.-K. Rao, X.-W. Su, Modified MSWI ash-mix slag for use in cement concrete, Constr. Build. Mater. 25 (2011) 1513-1520.

[11] C.C. Wiles, Municipal solid waste combustion ash: State-of-the-knowledge, J. Hazard. Mater. 47 (1996) 325-344.

[12] M. Li, J. Xiang, S. Hu, L.-S. Sun, S. Su, P.-S. Li, et al., Characterization of solid residues from municipal solid waste incinerator, Fuel 83 (2004) 1397-1405.

[13] H. a van der Sloot, D.S. Kosson, Hjelmar, Characteristics, treatment and utilization of residues from municipal waste incineration, Waste Manag. 21 (2001) $753-765$.

[14] N.-W. Kuo, H.-W. Ma, Y.-M. Yang, T.-Y. Hsiao, C.-M. Huang, An investigation on the potential of metal recovery from the municipal waste incinerator in Taiwan, Waste Manag. 27 (2007) 1673-1679.

[15] H. Ecke, H. Sakanakura, T. Matsuto, N. Tanaka, a. Lagerkvist, State-of-the-art treatment processes for municipal solid waste incineration residues in Japan, Waste Manag. Res. 18 (2000) 41-51.

[16] S.A.S. Abd Kadir, C.-Y. Yin, M. Rosli Sulaiman, X. Chen, M. El-Harbawi, Incineration of municipal solid waste in Malaysia: salient issues, policies and waste-to-energy initiatives, Renew. Sustain. Energy Rev. 24 (2013) 181-186.

[17] A. Bosmans, I. Vanderreydt, D. Geysen, L. Helsen, The crucial role of waste-toenergy technologies in enhanced landfill mining: a technology review, J. Clean. Prod. 55 (2013) 10-23.

[18] J.M. Chimenos, M. Segarra, M.A. Fernandez, F. Espiell, Characterization of the bottom ash in municipal solid waste incinerator, J. Hazard. Mater. 64 (1999) $211-222$.

[19] J. Pera, L. Coutaz, M. Chababbet, J. Ambroise, use of incineration bottom ash in concrete, Cem. Concr. Res. 27 (1997) 1-5.

[20] R. Siddique, Use of municipal solid waste ash in concrete, Resour. Conserv. Recycl. 55 (2010) 83-91.

[21] B. Juric, L. Hanzic, R. Ilić, N. Samec, Utilization of municipal solid waste bottom ash and recycled aggregate in concrete, Waste Manag. 26 (2006) 1436-1442.

[22] R. del Valle-Zermeño, J. Formosa, J.M. Chimenos, M. Martínez, a I. Fernández, Aggregate material formulated with MSWI bottom ash and APC fly ash for use as secondary building material, Waste Manag. 33 (2013) 621-627.

[23] N. Saikia, G. Cornelis, G. Mertens, J. Elsen, K. Van Balen, T. Van Gerven, et al., Assessment of Pb-slag, MSWI bottom ash and boiler and fly ash for using as a fine aggregate in cement mortar, J. Hazard. Mater. 154 (2008) 766-777.

[24] L. Bertolini, M. Carsana, D. Cassago, A. Quadrio Curzio, M. Collepardi, MSWI ashes as mineral additions in concrete, Cem. Concr. Res. 34 (2004) 1899-1906.

[25] A.A. Al-Rawas, A. Wahid Hago, R. Taha, K. Al-Kharousi, Use of incinerator ash as a replacement for cement and sand in cement mortars, Build. Environ. 40 (2005) 1261-1266.

[26] P. Tang, M.V.A. Florea, P. Spiesz, H.J.H. Brouwers, Characteristics and application potential of municipal solid waste incineration (MSWI) bottom ashes from two waste-to-energy plants, Constr. Build. Mater. 83 (2015) 77-94.

[27] P. Tang, M.V. Florea, P. Spiesz, H.J. Brouwers, The application of treated bottom ash in mortar as cement replacement, in: EurAsia Waste Manag. Symp. April 2014, YTU 2010 Congr. Center, Istanbul/Turkiye, 2014, pp. 1077-1082.

[28] R. Yang, W.-P. Liao, P.-H. Wu, Basic characteristics of leachate produced by various washing processes for MSWI ashes in Taiwan, J. Environ. Manage 104 (2012) 67-76.

[29] L. Su, G. Guo, X. Shi, M. Zuo, D. Niu, A. Zhao, et al., Copper leaching of MSWI bottom ash co-disposed with refuse: effect of short-term accelerated weathering, Waste Manag. 33 (2013) 1411-1417.

[30] U. Müller, K. Rübner, The microstructure of concrete made with municipal waste incinerator bottom ash as an aggregate component, Cem. Concr. Res. 36 (2006) 1434-1443.

[31] G. Pecqueur, C. Crignon, B. Quénée, Behaviour of cement-treated MSWI bottom ash, Waste Manag. 21 (2001) 229-233.

[32] M. Grosso, L. Biganzoli, L. Rigamonti, A quantitative estimate of potential aluminium recovery from incineration bottom ashes, Resour. Conserv. Recycl. 55 (2011) 1178-1184.

[33] S. Sorlini, A. Abbà, C. Collivignarelli, Recovery of MSWI and soil washing residues as concrete aggregates, Waste Manag. 31 (2011) 289-297.

[34] J. Yao, W.-B. Li, M. Tang, C.-R. Fang, H.-J. Feng, D.-S. Shen, Effect of weathering treatment on the fractionation and leaching behavior of copper in municipal solid waste incinerator bottom ash, Chemosphere 81 (2010) 571-576.

[35] X.-G. Li, Y. Lv, B.-G. Ma, Q.-B. Chen, X.-B. Yin, S.-W. Jian, Utilization of municipal solid waste incineration bottom ash in blended cement, J. Clean. Prod. 32 (2012) 96-100.

[36] GB 5085.3 Identification Standards for Hazardous Wastes - Identification for Extracton Toxicity, 2007.

[37] H.-S. Shi, L.-L. Kan, Leaching behavior of heavy metals from municipal solid wastes incineration (MSWI) fly ash used in concrete, J. Hazard. Mater. 164 (2009) 750-754.

[38] X.C. Oiao, M. Tyrer, C.S. Poon, C.R. Cheeseman, Novel cementitious materials produced from incinerator bottom ash, Resour. Conserv. Recycl 52 (2008) 496-510.

[39] S. Arickx, T. Van Gerven, T. Knaepkens, K. Hindrix, R. Evens, C. Vandecasteele, Influence of treatment techniques on $\mathrm{Cu}$ leaching and different organic fractions in MSWI bottom ash leachate, Waste Manag. 27 (2007) 1422-1427.

[40] J. Hyks, I. Nesterov, E. Mogensen, P.A. Jensen, T. Astrup, Leaching from waste incineration bottom ashes treated in a rotary kiln, Waste Manag. Res. 29 (2011) 995-1007.

[41] G. Cornelis, T. Van Gerven, C. Vandecasteele, Antimony leaching from MSWI bottom ash: modelling of the effect of $\mathrm{pH}$ and carbonation, Waste Manag. 32 (2012) 278-286.

[42] J.A. Meima, R.D. van der Weijden, T.T. Eighmy, R.N. Comans, Carbonation processes in municipal solid waste incinerator bottom ash and their effect on the leaching of copper and molybdenum, Appl. Geochem. 17 (2002) 1503-1513.

[43] J.A. Meima, R.N.J. Comans, The leaching of trace elements from municipal solid waste incinerator bottom ash at different stages of weathering 14 (1999) $159-171$.

[44] J.J. Dijkstra, H.A. Van Der Sloot, R.N.J. Comans, The leaching of major and trace elements from MSWI bottom ash as a function of $\mathrm{pH}$ and time, Appl. Geochem. 21 (2006) 335-351.

[45] J.M. Chimenos, A.I. Fernandez, R. Nadal, F. Espiell, Short term natural weathering of MSWI bottom ash, J. Hazard. Mater. B79 79 (2000) 287-299.

[46] NEN-EN 1744-7 Determination of Loss of Ignition of Municipal Incinerator Bottom Ash Aggregate (MIBA Aggregate), 2012.

[47] EN 196-1 Methods of Testing Cement - Part 1: Determination of Strength 2005.

[48] X.C. Qiao, M. Tyrer, C.S. Poon, C.R. Cheeseman, Characterization of alkaliactivated thermally treated incinerator bottom ash, Waste Manag. 28 (2008) 1955-1962.

[49] EN 1015-3 Methods of Test for Mortar for Masonry - Part 3: Determination of Consistence of Fresh Mortar (By Flow Table), 2007.

[50] NEN 7383 Uitloogkarakteristieken -Bepaling van de cumulative uitloging van anorganische componenten uit poeder- en korrelvormige materialen met een vereenvoudigde procedure voor de kolomproef-Vaste grond- en steenachtige materialen, 2003.

[51] NEN 6966 Environment-Analysis of Selected Elements in Water, Eluates and Destruates-Atomic Emission Spectrometry with Inductively Coupled Plasma, 2005.

[52] NEN-EN-ISO 10304-2 Water Quality-Determination of Dissolved Anions by Liquid Chromatography of Ions-Part 2: Determination of Bromide, Chloride Nitrate, Nitrite, Orthophosphate and Sulfate in Waste Water, 1996.

[53] Soil Quality Decree, 2008. https://zoek.officielebekendmakingen.nl/stb-2.

[54] NEN 6961 Milieu-Ontsluiting met salpeterzuur en zoutzuur (koningswater) voor de bepaling van geselecteerde elementen in water, waterbodem, slib, slibhoudend water, luchtstof, grond en bouwstoffen, 2005.

[55] NVN 7323 Uitloogkarakteristieken van vaste grond-en steenachtige bouwmaterialen en afvalstoffen-Bepaling van het gehalte van anorganische componenten-Bepaling van het gehalte van arseen, antimoon en seleen met atomaire-absorptiespectrometrie (hydrid), 1997.

[56] NEN-EN 1744-5 Test for chemical properties of aggregates-Part 5: Determination of acid soluble chloride salts, (n.d.).

[57] NEN-EN 1744-1 Tests for Chemical Properties of Aggregates-Part 1: Chemical Analysis, 2009.

[58] A. Saffarzadeh, T. Shimaoka, Y. Wei, K.H. Gardner, C.N. Musselman, Impacts of natural weathering on the transformation/neoformation processes in landfilled MSWI bottom ash: a geoenvironmental perspective, Waste Manag. 31 (2011) 2440-2454.

[59] S. Yang, A. Saffarzadeh, T. Shimaoka, T. Kawano, Existence of $\mathrm{Cl}$ in municipal solid waste incineration bottom ash and dechlorination effect of therma treatment, J. Hazard. Mater. 267C (2013) 214-220.

[60] G.-J. Song, K.-H. Kim, Y.-C. Seo, S.-C. Kim, Characteristics of ashes from different locations at the MSW incinerator equipped with various air pollution control devices, Waste Manag. 24 (2004) 99-106.

[61] Y.E. Yudovich, M.P. Ketris, Chlorine in coal: a review, Int. J. Coal Geol. 67 (2006) 127-144.

[62] J.M. Chimenos, A.I. Fernández, L. Miralles, M. Segarra, F. Espiell, Short-term natural weathering of MSWI bottom ash as a function of particle size, Waste Manag. 23 (2003) 887-895. 
[63] J. Yao, Q. Kong, H. Zhu, Y. Long, D. Shen, Content and fractionation of Cu, Zn and $\mathrm{Cd}$ in size fractionated municipal solid waste incineration bottom ash, Ecotoxicol. Environ. Saf. 94 (2013) 131-137.

[64] C.-H. Chen, I.-J. Chiou, Distribution of chloride ion in MSWI bottom ash and de-chlorination performance, J. Hazard. Mater. 148 (2007) 346-352.

[65] X.C. Qiao, B.R. Ng, M. Tyrer, C.S. Poon, C.R. Cheeseman, Production of lightweight concrete using incinerator bottom ash, Constr. Build. Mater. 22 (2008) 473-480.

[66] R. Gabrovšek, T. Vuk, V. Kaučič, Evaluation of the hydration of Portland cement containing various carbonates by means of thermal analysis, Acta Chim. Slov. 53 (2006) 159-165.

[67] R. Yu, P. Tang, P. Spiesz, H.J.H. Brouwers, A study of multiple effects of nanosilica and hybrid fibres on the properties of Ultra-High Performance Fibre Reinforced Concrete (UHPFRC) incorporating waste bottom ash (WBA) Constr. Build. Mater. 60 (2014) 98-110.

[68] H. Shi, L. Kan, Characteristics of municipal solid wastes incineration (MSWI) fly ash-cement matrices and effect of mineral admixtures on composite system, Constr. Build. Mater. 23 (2009) 2160-2166.

[69] N. Gineys, G. Aouad, D. Damidot, Managing trace elements in Portland cement - Part I: Interactions between cement paste and heavy metals added during mixing as soluble salts, Cem. Concr. Compos. 32 (2010) 563-570.

[70] C. Medina, P.F.G. Banfill, M.I. Sánchez de Rojas, M. Frías, Rheological and calorimetric behaviour of cements blended with containing ceramic sanitary ware and construction/demolition waste, Constr. Build. Mater. 40 (2013) $822-831$.

[71] D. Jansen, F. Goetz-Neunhoeffer, B. Lothenbach, J. Neubauer, The early hydration of Ordinary Portland Cement (OPC): an approach comparing measured heat flow with calculated heat flow from QXRD, Cem. Concr. Res. 42 (2012) 134-138.

[72] J.W. Bullard, H.M. Jennings, R.A. Livingston, A. Nonat, G.W. Scherer J.S. Schweitzer, et al., Mechanisms of cement hydration, Cem. Concr. Res, 41 (2011) 1208-1223.

[73] H. Taylor, Cement Chemistry, Second, Thomas Telford Publishing, 1997.

[74] R. Hooton, J. Tishmack, J. Olek, S. Diamond, Characterization of high-calcium fly ashes and their potential influence on ettringite formation in cementitious systems, Cem. Concr. Aggreg. 21 (1999) 82.

[75] I. Baur, P. Keller, D. Mavrocordatos, B. Wehrli, C.A. Johnson, Dissolution-precipitation behaviour of ettringite, monosulfate, and calcium silicate hydrate Cem. Concr. Res. 34 (2004) 341-348.
[76] Y. Shen, J. Qian, Z. Zhang, Investigations of anhydrite in CFBC fly ash as cement retarders, Constr. Build. Mater. 40 (2013) 672-678.

[77] M. Zajac, A. Rossberg, G. Le Saout, B. Lothenbach, Influence of limestone and anhydrite on the hydration of Portland cements, Cem. Concr. Compos. 46 (2014) 99-108.

[78] T. Matschei, B. Lothenbach, F.P. Glasser, The AFm phase in Portland cement, Cem. Concr. Res. 37 (2007) 118-130.

[79] P. Filipponi, A. Polettini, R. Pomi, P. Sirini, Physical and mechanical properties of cement-based products containing incineration bottom ash, Waste Manag. 23 (2003) 145-156.

[80] S.S. Jamkar, C.B.K. Rao, Index of aggregate particle shape and texture of coarse aggregate as a parameter for concrete mix proportioning, Cem. Concr. Res. 34 (2004) 2021-2027.

[81] L. Biganzoli, L. Gorla, S. Nessi, M. Grosso, Volatilisation and oxidation of aluminium scraps fed into incineration furnaces, Waste Manag. 32 (2012) $2266-2272$.

[82] M. Singh, R. Siddique, Effect of coal bottom ash as partial replacement of sand on properties of concrete, Resour. Conserv. Recycl 72 (2013) 20-32.

[83] M.V.A. Florea, H.J.H. Brouwers, Recycled concrete fines and aggregates: the composition of various size fractions related to crushing history, in: Proc. 18th Int. Conf. Build. Mater. (Ibausil), Weimar, 2012, pp. 1034-1041.

[84] M.V.A. Florea, H.J.H. Brouwers, The Influence of Crushing Method on Recycled Concrete Properties, 2013, pp. 1041-1050 (BT - Presentation at the international)

[85] M. Chen, J. Lin, S. Wu, C. Liu, Utilization of recycled brick powder as alternative filler in asphalt mixture, Constr. Build. Mater. 25 (2011) 1532-1536.

[86] Y.-N. Sheen, H.-Y. Wang, Y.-P. Juang, D.-H. Le, Assessment on the engineering properties of ready-mixed concrete using recycled aggregates, Constr. Build. Mater. 45 (2013) 298-305.

[87] P. Tang, M.V.A. Florea, H.J.H. Brouwers, The characterization of MSWI bottom ash, in: Proc. 18th Ibausil, Int. Conf. Build. Mater, 2012, 2-1162-2-1169.

[88] A. Polettini, R. Pomi, The leaching behavior of incinerator bottom ash as affected by accelerated ageing, J. Hazard. Mater. 113 (2004) 209-215.

[89] J.A. Meima, A van Zomeren, R.N.J. Comans, Complexation of Cu with dissolved organic carbon in municipal solid waste incinerator bottom ash leachates, Environ. Sci. Technol. 33 (1999) 1424-1429.

[90] S. Arickx, V. De Borger, T. Van Gerven, C. Vandecasteele, Effect of carbonation on the leaching of organic carbon and of copper from MSWI bottom ash, Waste Manag. 30 (2010) 1296-1302. 